\title{
ANALISIS LIKUIDITAS BANK MANDIRI TAHUN 2009-2013
}

\author{
Yuniman Zebua \\ Dosen Tetap Sekolah Tinggi Ilmu Ekonomi (STIE) Labuhanbatu
}

\begin{abstract}
ABSTRAK
Likuiditas Bank Mandiri merupakan kemampuan Bank Mandiri dalam memenuhi kewajibannya ketika jatuh tempo. Sebenarnya untuk mengetahui likuiditas sebuah perusahaan, banyak rasio yang digunakan sebagai alat ukurnya seperti current ratio, quick ratio, rasio solvabilitas, loan to deposite ratio, dan lain-lain. Dalam artikel ini, penulis membatasi rasio likuiditas yang digunakan yaitu hanya membahas dari aspek Loan Deposite Ratio (LDR). Loan to Deposite Ratio merupakan rasio perbandingan antara jumlah dana yang disalurkan ke masyarakat (kredit) dengan jumlah dana masyarakat dan modal sendiri yang digunakan. Loans to Deposite Rasio ini menggambarkan kemampuan bank membayar kembali penarikan yang dilakukan nasabah deposan dengan mengandalkan kredit yang diberikan sebagai sumber likuiditasnya. Berdasarkan data yang diperoleh menunjukkan bahwa likuiditas Bank Mandiri Cukup baik. Pada tahun 2009 LDR Bank Mandiri sebesar 59,15\%, pada tahun 2010 LDR Bank Mandiri sebesar 65,44\%, pada tahun 2011 LDR sebesar 71,65\%, dan pada tahun 2012 LDR sebesar 77,66\%, dan pada tahun 2013 LDR sebesar 82,97\%. Hal ini menunjukkan bahwa nilai rasio Loan to Deposite Ratio (LDR) masih berada pada kategori Bank sehat.
\end{abstract}

Kata Kunci : Likuiditas, Loan Deposite Ratio (LDR).

\section{Pendahuluan}

Bank sebagai lembaga kepercayaan mempunyai fungsi utama sebagai lembaga intermediasi, yaitu menghimpun dana dari masyarakat dan menyalurkannya secara efektif dan efisien pada sektor-sektor riil. Sebagaimana dijelaskan dalam Undang-Undang No.7 Tahun 1992 tentang perbankan dan telah diubah dengan Undang-Undang No.10 tahun 1998 bahwa bank adalah badan usaha yang menghimpun dana dari masyarakat dalam bentuk simpanan dan menyalurkannya kepada masyarakat dalam bentuk kredit dan atau bentuk-bentuk lainnya dalam rangka meningkatkan taraf hidup rakyat banyak.

Dalam menjalankan fungsinya, penting bagi bank untuk menjaga tingkat kepercayaan masyarakat. Masyarakat berharap dana yang mereka simpan di bank akan aman. Untuk itu bank harus menjaga tingkat kesehatannya karena bank yang sehat adalah bank yang dapat menjaga dan memelihara kepercayaan masyarakat, dapat membantu kelancaran lalulintas pembayaran serta dapat digunakan oleh pemerintah dalam melaksanakan berbagai kebijakannya, terutama kebijakan moneter. Dalam menjalankan kegiatan intermediasinya bank harus memperhatikan likuiditasnya yaitu terjadinya penarikan dana simpanan maupun pinjaman dengan tetap berupaya menjaga profitabilitasnya, untuk itu bank harus berhati-hati dalam menjalankan kegiatan operasionalnya.

Dalam memberikan kredit kepada masyarakat, Bank Mandiri tentu saja memiliki pedoman atau standar prosedur untuk menghindari resiko bisnis. Sebagai pedoman dalam pengelolaan kredit secara end-to-end, Bank Mandiri memiliki Kebijakan Perkreditan BankMandiri (KPBM), termasuk didalamnya Budaya Kredit dan Doktrin Perkreditan. Penjabaran kebijakan kredit secaraoperasional dituangkan dalam bentuk Standar Prosedur Kredit (SPK) dan Manual Produk. Proses pengelolaan kreditdiawali dengan penetapan target market, melakukan risk 
assessment dan monitoring atas pemberian kredit.Bank Mandiri menerapkan prinsip kehatihatian dalam pemberian kredit, dimana fungsi analisis kredit dilakukanoleh unit bisnis dan unit risiko kredit yang independen, fungsi persetujuan kredit dilakukan secara " 4 eyes principle"dan fungsi administrasi kredit dilakukan oleh unit credit operation yang independen terhadap unit bisnis dan unitrisiko kredit.

Persetujuan dan penetapan limit kredit pada segmen corporate, commercial, dan business banking (limit Rp5 Miliars.d. Rp10 Miliar) diidentifikasi dan diukur melalui sistem credit rating yang kemudian dilakukan analisa kelayakanbisnis melalui spreadsheet dan Nota Analisa Kredit (NAK) secara terintegrasi dan end-to-end melalui IntegratedProcessing System (IPS).Sedangkan pada segmen retail (business banking dengan limit Rp500 Juta s.d. Rp5 Miliar \& mikro) dan consumerdiukur melalui sistem credit scoring. Proses kredit dan pengelolaan risiko kredit segmen mikro dan consumerdilakukan melalui proses end-to-end yang terintegrasi dalam sistem Loan Origination System (LOS).

Selama tahun 2013, Bank Mandiri membukukan pertumbuhan kredit yang cukup signifikan dengan tingkat NPL yang terjaga. Portfolio kredit Bank Mandiri untuk keseluruhan segmen (posisi bank secara individual) tumbuh 22,65\% (YoY) dengan tingkat NPL 1,60\% (gross). Beberapa segmen kredit mengalami pertumbuhan di atas ratarata,

seperti segmen micro \& retail banking yang tumbuh sebesar 42,3\% (YoY) namun dengan tingkat NPL yang terjaga sekitar 3\%. Pencapaian tersebut didapatkan melalui penerapan proses kredit secara terintegrasi (end-toend) dan handal, yang meliputi proses identifikasi sektor kredit yang potensial, proses underwriting yang akurat dan ketat, proses monitoring kredit secara kontinu, portfolio management yang komprehensif dan penyelesaian kredit bermasalah secara disiplin.

Salah satu ukuran untuk melihat likuiditasperbankan adalah Loan to Deposit Ratio (LDR). LDR mengukur efektivitas perbankan dalam penyaluran kredit melalui dana yang berhasil dihimpun dari masyarakat. LDR menyatakan seberapa jauh kemampuan bank dalam membayar penarikan dana yang dilakukan deposan dengan mengandalkan kredit yang diberikan sebagai sumber likuiditasnya (Dendawijaya, 2009). Jadi, seberapa jauh pemberian kredit kepada nasabah dapat mengimbangi kewajiban bank untuk segera memenuhi permintaan deposan yang ingin menarik uangnya yang telah digunakan oleh bank untuk memberikan kredit.

Tingginya rasio tersebut mengindikasikan semakin baik kemampuan bank yang bersangkutan. Hal ini disebabkan jumlah dana yang diperlukan untuk membiayai kredit menjadi semakin besar. Rasio ini juga merupakan indikator kerawanan dan kemampuan suatu bank. Sebagian praktisi perbankan menyepakati bahwa batas aman dari Loan to Deposit Ratio (LDR) suatu bank adalah sekitar $80 \%$. Namun batas toleransi berkisar antara $85 \%$ dan $100 \%$. Karena alasan tersebut sehingga dalam penelitian ini menggunakan Loan to Deposit Ratio (LDR) sebagai indikator pengukur fungsi intermediasi perbankan.

Pada sisi pasiva, bank harus mampu memenuhi kewajiban kepada nasabah setiap simpanan mereka yang ada di bank ditarik, pada sisi aktiva bank harus menyanggupi pencairan kredit yang telah diperjanjikan. Bila kedua aspek atau salah satu aspek ini tidak dapat dipenuhi, maka bank akan kehilangan kepercayaan masyarakat. Likuiditas bank adalah kemampuan bank untuk memenuhi kemungkinan ditariknya deposito atau simpanan oleh deposan atau penitip dana ataupun memenuhi kebutuhan masyarakat berupa kredit (Kasmir, 2008:286).

LDR adalah rasio keuangan perusahaan perbankan yang berhubungan dengan aspek likuiditas. LDR adalah suatu pengukuran tradisional yang menunjukkan deposito berjangka, giro, tabungan, dan lain-lain yang digunakan dalam memenuhi permohonan pinjaman (loan requests) nasabahnya. Rasio ini digunakan untuk mengukur tingkat likuiditas.

\section{Batasan Masalah}


Penulisan artikel ini dibatasi hanya melihat likuiditas Bank Mandiri dari tahun 2009 sampai tahun 2013. Penulis hanya membahas likuiditas dari aspek Loan to Deposite Ratio.

\section{Perumusan Masalah}

Dari latar belakang masalah, perumusan dalam artikel ini adalah bagaimana likuiditas Bank Mandiri dari tahun 2009-2013.

\section{Tujuan}

Sesuai dengan masalah yang telah dirumuskan, maka tujuan artikel ini adalah untuk mengungkapkan likuiditas bank mandiri tahun 2009-2013.

\section{Tinjauan Teoritis}

\section{Pengertian Bank}

Perbankan secara umum merupakan lembaga keuangan yang melakukan kegiatan berupa pengumpulan dana masyarakat dan menyalurkannya kembali kepada masyarakat dalam berbagai bentuk. Di Indonesia sendiri, bank merupakan sumber utama pembangunan.Pengertian perbankan menurut UU No. 10 Tahun 1998 tentang perusahaan atas UU N0. 7 Tahun 1992 tentang perbankan Bab I pasal 1 ayat (1) adalah segala sesuatu yang menyangkut tentang bank, mencakup tentang kelembagaan, kegiatan usaha, serta cara dan proses dalam melaksanakan kegiatan usahanya."

Berbagai definisi mengenai bank telah dikemukakan oleh berbagai kalangan dan ahli. Berikut ini beberapa pengertian bank antara lain :

1. Menurut Undang-Undang Republik Indonesia No. 10 Tahun 1998 tentang Perbankan,. "Bank adalah badan usaha yang menghimpun dana dari masyarakat dalam bentuk simpanan dan menyalurkannya dalam bentuk kredit dan atau bentuk-bentuk lainnya dalam rangka meningkatkan taraf hidup rakyat banyak. Bank Umum adalah bank yang melaksanakan kegiatan usaha secara konvensional dan atau berdasarkan Prinsip Syariah yang dalam kegiatannya memberikan jasa dalam lalu lintas pembayaran.Bank Perkreditan Rakyat adalah bank yang melaksanakan kegiatan usaha secara konvensional atau berdasarkan Prinsip Syariah yang dalam kegiatannya tidak memberikan jasa dalam lalu lintas pembayaran."

2. Menurut Undang-Undang Republik Indonesia No. 23 Tahun 1999 adalah sebagai berikut :

"bank adalah Bank Umum dan Bank Perkreditan Rakyat sebagaimana dimaksud dalam undang-undang tentang perbankan yang berlaku."

3. Bank secara sederhana menurut Kasmir (2002:11) adalah :

"Lembaga keuangan yang kegiatan utamanya adalah dengan menghimpun dana dari masyarakat dan menyalurkannya kembali dana tersebut ke masyarakat serta memberikan jasa Bank lainnya."

4. Abdullah (2005) mendefinisikan bank sebaga berikut :

"bank merupakan bagian dari lembaga keuangan yang memiliki fungsi intermediasi yaitu menghimpun dana dari masyarakat yang kelebihan dana dan menyalurkan dana yang dihimpunnya kepada masyarakat yang kekurangan dana."

\section{Likuiditas}


Menurut Kasmir (2012:128) merupakan kemampuan perusahaan dalam membayar kewajibannya ketika jatuh tempo. Ketidakmampuan perusahaan membayar kewajibannya terutama jangka pendek (yang sudah jatuh tempo) disebabkan oleh berbagai faktor, yaitu:

1. Bisa dikarenakan memang perusahaan sedang tidak memiliki dana sama sekali, atau

2. Bisa mungkin saja perusahaan memiliki dana, namun saat jatuh tempo perusahaan tidak memiliki dana (tidak cukup dana secara tunai sehingga harus menunggu dalam waktu tertentu, untuk mencairkan aktiva lainnya seperti menagih piutang, menjual surat-surat berharga, atau menjual sediaan atau aktiva lainnya). Pengertian rasio likuiditas menurut

Brigham dan Houston dalam bukunya "Dasar- dasar Manajemen Keuangan" (2010:134), mengatakan bahwa : "aset likuid merupakan asset yang diperdagangkan di pasar aktif sehingga dapat dikonversi dengan cepat menjadi kas pada harga pasar yang berlaku, sedangkan posisi likuiditas suatu perusahaan berkaitan dengan pertanyaan, apakah perusahaan mampu melunasi utangnya ketika utang tersebut jatuh tempo di tahun berikutnya." Menurut Kasmir (2003), Loan to deposit ratio ( LDR ) merupakan salah satu Likuiditas yg sering digunakan untuk menilai kinerja suatu bank.

\section{Loan Deposite Ratio (LDR)}

LDR menyatakan seberapa jauh kemampuan bank dalam membayar penarikan dana yang dilakukan deposan dengan mengandalkan kredit yang diberikan sebagai sumber likuiditasnya (Dendawijaya, 2009). Jadi, seberapa jauh pemberian kredit kepada nasabah dapat mengim-bangi kewajiban bank untuk segera memenuhi permintaan deposan yang ingin menarik uangnya yang telah digunakan oleh bank untuk memberikan kredit.

Tingginya rasio tersebut mengindikasikan semakin baik kemampuan bank yang bersangkutan. Hal ini disebabkan jumlah dana yang diperlukan untuk membiayai kredit menjadi semakin besar. Rasio ini juga merupakan indikator kerawanan dan kemampuan suatu bank. Sebagian praktisi perbankan menyepakati bahwa batas aman dari Loan to Deposit Ratio (LDR) suatu bank adalah sekitar $80 \%$. Namun batas toleransi berkisar antara $85 \%$ dan $100 \%$.

Pada sisi pasiva, bank harus mampu memenuhi kewajiban kepada nasabah setiap simpanan mereka yang ada di bank ditarik, pada sisi aktiva bank harus menyanggupi pencairan kredit yang telah diperjanjikan. Bila kedua aspek atau salah satu aspek ini tidak dapat dipenuhi, maka bank akan kehilangan kepercayaan masyarakat. (Kasmir, 2008:286).

LDR adalah rasio antara seluruh kredit yang diberikan bank dengan dana yang diterima bank. Rasio ini menunjukkan salah satu penilaian likuiditas bank. LDR menyatakan seberapa jauh kemampuan bank membayar kembali penarikan yang dilakukan nasabah deposan dengan mengandalkan kredit yang diberikan sebagai sumber likuiditasnya. Semakin tinggi rasio ini semakin rendah pula kemampuan likuiditas bank yang bersangkutan. Rasio yang tinggi menunjukkan bahwa suatu bank meminjamkan seluruh dananya (loan-up) atau relatif tidak likuid (illiquid). Sebaliknya rasio yang rendah menunjukkan bank yang likuid dengan kelebihan kapasitas dana yang siap untuk dipinjamkan. Hal ini karena jumlah dana yang diperlukan untuk membiayai kredit menjadi semakin besar (Dendawijaya, 2009:116). Rasio ini juga merupakan indikator kerawanan dan kemampuan dari suatu bank. Sebagian praktisi perbankan menyepakati bahwa batas aman dari LDR suatu bank adalah sekitar $80 \%$. Namun ratio menurut peraturan pemerintah maksimum adalah 110\% (Kasmir, 2008:290).

Pengertian Loan to Deposit Ratio (LDR) menurut Martono (2002:82) menyatakan bahwa : "Loan to Deposit Ratio adalah rasio untuk mengetahui kemampuan bankdalam membayar kembali kewajiban kepada nasabah yang telahmenanamkan dananya dengan kredit-kredit yang telah diberikan kepadapara debiturnya."

Menurut Mulyono (2001:101), Loan to Deposit Ratio (LDR) merupakan rasio perbandingan antara jumlah dana yang disalurkan ke masyarakat (kredit) dengan jumlah dana masyarakat dan modal sendiri yang digunakan. Loans Rasio ini menggambarkan kemampuan 
bank membayar kembali penarikan yang dilakukan nasabah deposan dengan mengandalkan kredit yang diberikan sebagai sumber likuiditasnya.

Dari penjelasan diatas dapat disimpulkan bahwa Loan To Deposit Ratio (LDR) merupakan kemampuan Bank dalam membayar kembali dana penarikan yang telah dilakukan oleh deposan dengan mengandalkan kredit untuk mengetahui tingkat likuidasinya.

Ketentuan Loan to Deposit Ratio menurut Bank Indonesia pada surat edaran Bank Indonesia No. 26/5/BPPP tanggal 29 Mei 1993 perihal tata cara penilaian tingkat kesehatan bank umum, menyatakan bahwa tingkat kesehatan bank untuk kepentingan semua pihak yang terkait, maka Bank Indonesia menetapkan :

1. Untuk Loan to Deposit Ratio sebesar $110 \%$ atau lebih diberi nilai kredit nol (0), artinya likuiditas bank tersebut tidak sehat.

2. Untuk Loan to Deposit Ratio di bawah $110 \%$ diberi nilai kredit 100, artinya likuiditas bank tersebut sehat. Batas aman Loan to Deposit Ratio suatu bank secara umum adalah sekitar 90\%-100\%, sedangkan menurut ketentuan bank sentral batas aman Loan to Deposit Ratio adalah 110\% (Simorangkir, 2000:147).

Rasio ini juga merupakan indikator kerawanan dan kemampuan suatu bank, dimana sebagian praktisi perbankan menyepakati bahwa batas aman Loan to Deposit Ratio dari suatu bank adalah $80 \%$. Namun, batas toleransi berkisar antara

$85 \%-110 \%$.

Dalam tata cara penilaian tingkat kesehatan bank, bank Indonesia menetapkan ketentuan sebagai berikut :

1. Untuk rasio LDR sebesar $110 \%$ atau lebih diberikan nilai kredit 0 , artinya likuiditas bank tersebut dinilai tidak sehat.

2. Untuk rasio LDR di bawah $110 \%$ diberikan nilai kredit 100 , artinya likuiditas bank dinilai sehat.

Jadi dapat disimpulkan bahwa Loan To Deposit Ratio (LDR) yang terlalu tinggi memberikan indikasi semakin rendahnya kemampuan likuiditas bank yang bersangkutan, hal ini disebabkan karena jumlah dana yang diperlukan untuk membiayai kredit menjadi semakin besar. Sebaliknya, jika Loan to Deposit Ratioyang rendah menunjukkan tingkat ekspansi kredit yang rendah dibandingkan dengan dana yang diterimanya

\section{Pengertia Kredit}

Menurut Iswi Hariyani $(2010,10)$ menyatakan "Kredit yang diberikan oleh bank didasarkan atas kepercayaan sehingga pemberian kredit merupakan pemberian kepercayaan kepada nasabah".

Sedangkan pengertian kredit dijelaskan oleh PAPI revisi 2001 dalam Eddie Rinaldy $(2009,29)$ :Kredit adalah penyediaan uang atau tagihan yang dapat dipersamakan dengan itu, berdasarkan persetujuan atau kesepakatan pinjam meminjam antara bank dan pihak lain yang mewajibkan pihak peminjam (debitur) untuk melunasi hutangnya setelah jangka waktu tertentu dengan jumlah bunga, imbalan atau pembagian hasil keuntungan . Termasuk dalam pengertian kredit dalam restrukturisasi, dan pembelian surat berharga debitur yang dilengkapi dengan note purchase agreement atau NPA.

Dari pengertian yang dikemukakan beberapa ahli, dapat disimpulkan bahwa kredit adalah semua pinjaman yang didasarkan oleh kepercayaan bahwa debitur akan mengembalikan pinjaman beserta bunganya sesuai perjanjian yang telah disepakati.

\section{Pembahasan}

LDR merupakan untuk mengukur komposisi jumlah kredit yang diberikan dibanding dengan jumlah dana masyarakat dan modal sendiri yang digunakan. BerdasarkanPeraturan Bank Indonesia Nomor: 6/10/Pbi/2004 Tentang Sistem Penilaian Tingkat Kesehatan Bank 
Umum, Penilaian Tingkat Kesehatan Bank Mencakup Penilaian Terhadap Faktor-Faktor Sebagai Berikut:

a. permodalan (capital);

b. kualitas aset (asset quality);

c. manajemen (management);

d. rentabilitas (earning);

e. likuiditas (liquidity); dan

f. sensitivitas terhadap risiko pasar (sensitivity to market risk).

Dalam artikel ini, penulis akan membahasan tingkat kesehatan Bank Mandiri dari segi likuiditas Bank Mandiri selama periode tahun 2009-2013. Likuiditas merupakan kemampuan dalam memenuhi kewajiban jangka pendek (John J.Wild, 2005:38). Suatu bank dapat dikatakan likuid, apabila bank yang bersangkutan dapat membayar semua hutang-hutangnya terutama simpanan tabungan, giro dan deposito pada saat ditagih dan dapat pula memenuhi semua permohonan kredit yang memang layak untuk dibiayai (Kasmir, 2002:48).

Untuk mengukur rasio likuiditas, banyak rasio yang dapat digunakan seperti Cash Ratio ( CR ), Reserve Requirement ( RR ), Loan to deposit ratio ( LDR ), Loan to asset ratio ( LAR ), Rasio kewajiban bersih Call Money (NCM). Namun penulis hanya mempersempit lingkup pemabahasan pada rasio Loan to deposite ratio (LDR). Loan to Deposit Ratio merupakan perbandingan antara jumlah kredit yang disalurkan terhadap jumlah dana pihak ketiga yang dihimpun. Jika bank dapat menyalurkan seluruh dana yang dihimpun, hal itu akan sangat menguntungkan. Namun, itu akan sangat terkait dengan risiko apabila sewaktu-waktu pemilik dana menarik dananya atau pemakai dana tidak dapat mengembalikan dana yang dipinjamnya. Sebaliknya, apabila bank tidak menyalurkan dananya maka bank juga akan terkena risiko karena hilangnya kesempatan untuk memperoleh keuntungan.

Berdasarkan data yang diperoleh dari laporan tahunan Bank Mandiri tahun 2013, Likuiditas Bank Mandiri dari aspek rasio Loan to Deposit Ratio(LDR) adalah sebagai berikut

Tabel 1

Data Likuiditas Bank Mandiri Tahun 2009-2013

\begin{tabular}{|c|c|}
\hline Iáur: & Lkidits (LE) \\
\hline 2009 & $59,15 \%$ \\
\hline 2210 & $65,44 \%$ \\
\hline 2011 & 1..55\% \\
\hline 2012 & $11,56 \%$ \\
\hline 2013 & $3297 \%$ \\
\hline
\end{tabular}

Sumber : Laporan tahunan Bank Mandiri tahun 2013

Berdasarkan Tabel 1 di atas loan Deposite Ratio Bank Mandiri dari tahun 2009 sampai tahun 2013 tidak terlalu tinggi dan juga tidak terlalu rendah. Hal ini menunjukkan likuiditas Bank Mandiri masuk kedalaam kategori sehat. Pada tahun 2009 LDR Bank Mandiri sebesar 59,15\%, pada tahun 2010 LDR Bank Mandiri sebesar 65,44\%, pada tahun 2011 LDR sebesar 71,65\%, dan pada tahun 2012 LDR sebesar 77,66\%, dan pada tahun 2013 LDR sebesar $82,97 \%$. Sebagaiman kita ketahui bahwa apabila LDR perbankan terlalu tinggi menunjukkan rendahnya likuiditas perbankan tersebut. Hal ini disebabkan dana yang diperlukan untuk membiaya kredit juga semakin besar. Sebaliknya apabila terlalu rendah juga menunjukkan rendahnya kredit yang disalurkan dibandingakn dengan dana yang diterimanya.

Semakin tinggi Loan to Deposit Ratio memberikan indikasi semakin rendahnya kemampuan likuiditas bank yang bersangkutan, hal ini disebabkan karena jumlah dana yang diperlukan untuk membiayai kredit menjadi semakin besar. Sebaliknya, angka Loan to Deposit 
Ratio yang rendah menunjukkan tingkat ekspansi kredit yang rendah dibandingkan dengan dana yang diterimanya.

Hingga tanggal 31 Desember 2013, jumlah kredit yang diberikan Bank Mandiri adalah sebesarRp416.978 Miliar. Jumlah tersebut meningkat sebesar 22,7\% dibandingkan dengan posisi 31 Desember 2012 yangsebesar Rp339.974 Miliar. Aset Bank Mandiri di posisi akhir tahun 2013 menunjukkan peningkatan dari Rp635,62 Triliun di tahun 2012 menjadi Rp733,10 Triliun di tahun 2013, atau naik sebesar 15,3\%. Peningkatan aset ini dipicu dari peningkatankredit, pembiayaan konsumen dan investasi bersih dalam sewa pembiayaan dari Rp388,83 Triliun di tahun 2012 menjadi Rp472,43 Triliun di tahun 2013. Peningkatan tersebut berasal dari peningkatan total kredit (tidak termasuk pembiayaan konsumen dan investasi bersih dalam sewa pembiayaan) yang diberikan dari Rp384,58 Triliun di tahun 2012 menjadi Rp467,17 Triliun di tahun 2013 atau naik sebesar 21,5\%.

(Sumber : Laporan Tahunan Bank Mandiri 2013).

\section{Kesimpulan Dan Saran}

Likuiditas Bank Mandiri sudah baik Pada tahun 2009 LDR Bank Mandiri sebesar 59,15\%, pada tahun 2010 LDR Bank Mandiri sebesar 65,44\%, pada tahun 2011 LDR sebesar 71,65\%, dan pada tahun 2012 LDR sebesar 77,66\%, dan pada tahun 2013 LDR sebesar $82,97 \%$. Penulis menyarankan agar dipertahankan dan ditingkatkan lagi

\section{Daftar Pustaka}

Hariyani, Iswi. 2010. Restrukturisasi dan Penghapusan Kredit Macet .Cetakan Pertama. Jakarta: PT. Elex Media Komputindo

Kasmir 2010. Bank dan Lembaga Keuangan Lainnya. Raja Graffindo Pers. Jakarta.

UU No. 10 Tahun 1998 tentang perusahaan atas UU N0. 7 Tahun 1992 tentang perbankan

Pedoman Akuntansi Perbankan Indonesia atau PAPI, revisi 2001

Peraturan Bank Indonesia Nomor: 6/10/Pbi/2004 Tentang Sistem Penilaian Tingkat Kesehatan Bank Umum.

Laporan Tahunan Bank Mandiri 2013 